\title{
Impact of climate change on direct and indirect species interactions
}

\author{
Joshua P. Lord*, James P. Barry, Dale Graves \\ Monterey Bay Aquarium Research Institute, 7700 Sandholdt Rd, Moss Landing, CA 95039, USA
}

\begin{abstract}
Recent marine climate change research has largely focused on the response of individual species to environmental changes including warming and acidification. The response of communities, driven by the direct effects of ocean change on individual species as well the cascade of indirect effects, has received far less study. We used several rocky intertidal species including crabs, whelks, juvenile abalone, and mussels to determine how feeding, growth, and interactions between species could be shifted by changing ocean conditions. Our 10 wk experiment revealed many complex outcomes which highlight the unpredictability of community-level responses. Contrary to our predictions, the largest impact of elevated $\mathrm{CO}_{2}$ was reduced crab feeding and survival, with a $\mathrm{pH}$ drop of 0.3 units. Surprisingly, whelks showed no response to higher temperatures or $\mathrm{CO}_{2}$ levels, while abalone shells grew $40 \%$ less under high $\mathrm{CO}_{2}$ conditions. Massive non-consumptive effects of crabs on whelks showed how important indirect effects can be in determining climate change responses. Predictions of species outcomes that account solely for physiological responses to climate change do not consider the potentially large role of indirect effects due to species interactions. For strongly linked species (e.g. predator-prey or competitor relationships), the indirect effects of climate change are much less known than direct effects, but may be far more powerful in reshaping future marine communities.
\end{abstract}

KEY WORDS: Climate change - Ocean acidification - Global warming - Species interactions . Predation

${ }^{*}$ Corresponding author: joshua.p.lord@gmail.com

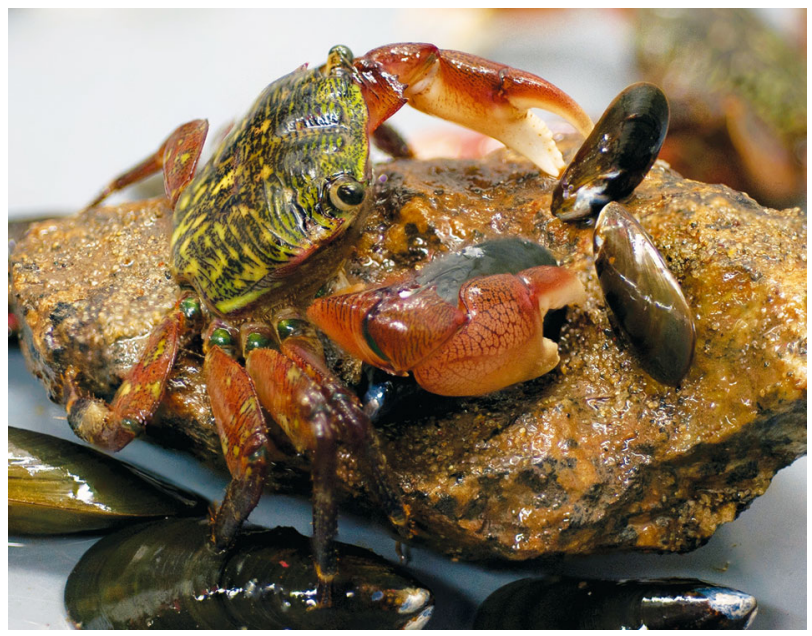

Ocean acidification may cause cascading changes in food webs by shifting predator-prey relationships between species like lined shore crabs and mussels.

Photo: Todd Walsh, MBARI

\section{INTRODUCTION}

Indirect interactions (e.g. trophic cascades) are pervasive in complex biological systems, and may be more influential than direct interactions (e.g. competition, predation) across populations and species, but they are often understudied (Strauss 1991, Schmitz et al. 2004). These indirect effects are the mechanism by which carnivores affect plant communities and top predators influence primary consumers, creating a high degree of complexity in marine and terrestrial food webs (Schmitz et al. 2004). This interplay between the direct responses of species to environmental change, and the nature, linkages, and strength

(C) The authors and Monterey Bay Aquarium Research Institute 2017. Open Access under Creative Commons by Attribution Licence. Use, distribution and reproduction are unrestricted. Authors and original publication must be credited.

Publisher: Inter-Research · www.int-res.com 
of species interactions throughout biological communities, is largely unexplored, especially in marine systems.

Climate change affects species in many habitats, but few studies have examined the response of marine communities to changing environmental conditions (Walther et al. 2002). Rising atmospheric partial pressure of $\mathrm{CO}_{2}\left(\mathrm{pCO}_{2}\right)$ and warming can influence terrestrial and freshwater species, and the impacts of climate change may be striking in marine systems, where species must cope with both warming seawater temperatures and ocean acidification (OA) (Loiterton et al. 2004, Shimono \& Bunce 2009, Hofmann et al. 2010). In surface waters throughout the global ocean, temperature will likely rise by an average of 3 to $5^{\circ} \mathrm{C}$ by 2100 , while pH drops approximately 0.3 units, drastically altering the environment in which many marine organisms live (IPCC 2014).

Ocean warming can affect growth, feeding, and mortality of many marine species, with a general increase in growth of calcifying organisms at warmer temperatures due to higher carbonate saturation in the water (Morse \& Mackenzie 1990, Elliott \& Leggett 1996, Sanford 1999, Lord \& Whitlatch 2013). Impacts of OA on individual species have also been well documented; these include negative effects on various physiological processes that influence growth, feeding, and survival of marine organisms, especially mollusks (Comeau et al. 2009, Nienhuis et al. 2010, Gaylord et al. 2011, Sanford et al. 2014). More recently, there has been a push to include multiple factors to examine the combined effects of increasing $\mathrm{pCO}_{2}$ and temperature, although these studies have focused primarily on individual species (Davis et al. 2013, Gaylord et al. 2015).

Community-level responses to climate change are far more complex and unpredictable than for single species, owing to the effects of species interactions. Recent reviews of climate change in marine systems have placed high priority on experiments examining how environmental change may affect species interactions (Kroeker et al. 2013, Coleman et al. 2014, Gaylord et al. 2015). Gaylord et al. (2015) wrote that 'the biggest unknown of OA research is how species will respond within the context of their communities' (p. 5). Studies of multi-species responses have discovered simultaneous changes in feeding and susceptibility to predation, as well as changes in species diversity and abundance (Hale et al. 2011, Queirós et al. 2015).

Considering that most research examining the consequences of warming and acidification has tested direct responses of individual species (growth, fertiliza- tion, larval survival), there is a pressing need to explore indirect species interactions as well. Indirect effects, through which a shift in the relationship between 2 species affects a third species, play an important role in many systems (Menge 1995, Schmitz et al. 1997, Werner \& Peacor 2003, Preisser et al. 2005, Trussell et al. 2006). In particular, trait-mediated indirect interactions (TMIIs) are those in which a predator can influence the relationship between 2 other species, such as when the presence of crabs causes a reduction in whelk feeding rates on barnacles (Aschaffenburg 2008). The effect of TMIIs can be substantial because they affect entire populations, not just some individuals (as is the case for predation), but few studies have examined how these important interactions can be impacted by climate change (Peacor \& Werner 2001).

\section{MATERIALS AND METHODS}

\section{Experimental approach}

Our experiments focused on organisms from rocky intertidal habitats in the northeast Pacific: crabs, whelks, abalone, mussels, and seaweed. We used the lined shore crab Pachygrapsus crassipes Randall, 1840 , because it is a common ${ }^{\mathbf{1}}$, major predator of small invertebrates, so shifts in its populations with climate change could have substantial effects on rocky shore communities (Armitage \& Fong 2006, Cassone \& Boulding 2006, Clemente et al. 2013, Lord \& Barry 2017). We targeted 2 sets of interactions: (1) crabs (P. crassipes), whelks (Nucella ostrina Gould, 1852), and mussels (Mytilus galloprovincialis Lamarck, 1819); and (2) crabs, abalone (Haliotis rufescens Swainson, 1822), and seaweed (sea lettuce Ulva lactuca). The intertidal ranges of $P$. crassipes and $N$. ostrina overlap considerably, and M. galloprovincialis is a common invasive mussel in protected bays and estuaries where P. crassipes is common (Braby \& Somero 2006). The whelk $N$. ostrina is often found in more wave-exposed areas than $M$. galloprovincialis, but the 2 species co-occur in several locations including Moss Landing, California (USA), the site of the present study. For the second set of species, we selected the commercially important $H$. rufescens as a representative abalone because $P$. crassipes can consume juvenile abalone, and $H$. rufescens juveniles are available via aquaculture, unlike the intertidal black abalone $H$. cracherodii. Predation by $P$. crassipes on whelks,

\footnotetext{
1 Partnership for Interdisciplinary Studies of Coastal Oceans [PISCO] surveys found up to $200 \mathrm{~m}^{-2}$ (http://data.piscoweb.org)
} 
mussels, and abalone has only recently been described (Lord \& Barry 2017), so this study is the first to describe direct and indirect effects between $P$. crassipes and these other invertebrates. The goal of the experiment was to use these representative species to gain an understanding of how changing climate could affect species interactions in intertidal communities.

We exposed groups of these species to elevated temperatures or high $\mathrm{CO}_{2}$ or both to determine if species interactions were affected by ocean change, and if ecological interactions could be predicted from the individual species' responses to changing conditions. We hypothesized that direct effects of climate change (elevated temperature and $\mathrm{CO}_{2}$ ) would be minimal for crabs because they are calcified to a lesser extent than mollusks, but would lead to reduced shell growth for whelks and abalone due to the decrease in carbonate saturation states (Waldbusser et al. 2015). We further hypothesized that indirect effects of elevated temperature and $\mathrm{CO}_{2}$ would include lower feeding on mussels and seaweed by whelks and abalone, respectively. Over the long run, this could result in declines in whelk and abalone populations due to the relatively robust response of crabs and the negative impacts of OA on mollusk shell production. Assessing the relative importance of direct and indirect effects arising with changing environmental factors should provide a more comprehensive framework for assessing community-level responses to changing ocean conditions.

\section{Experimental set-up}

We collected crabs (20-30 mm carapace width) from Moss Landing Harbor and whelks $(\sim 10 \mathrm{~mm}$ shell length [SL]) from the rocky intertidal zone near Point Joe, California. Mussels (10-30 mm SL) and juvenile abalone (15 mm SL) were purchased from Kamilche Sea Farms and the Monterey Abalone Company, respectively. We chose intermediate sizes of crabs, whelks, and mussels to minimize variability, and used juvenile abalone because adults are not vulnerable to predation by $P$. crassipes; mean sizes of all experimental animals are shown in Table 1. Sea lettuce, a preferred seaweed for juvenile abalone, was also collected from Moss Landing Harbor (Evans \& Langdon 2000). All animals were acquired in March 2016, then held in aquaria with flowing seawater for $1 \mathrm{wk}$ prior to experiments. Although crabs, whelks, and mussels in these experiments are intertidal in nature, all species were immersed in seawater throughout the experiments to ensure that their exposure time was equal for all seawater treatments. Thus, this study did not incorporate the impacts on stress, feeding, or growth that may result from fluctuations in aerial temperatures associated with climate change.

The experimental setup was a full factorial design, with 71 rectangular polypropylene containers $(\mathrm{n}=$ 64) as experimental tanks and 3 experimental factors (2 levels each of temperature, $\mathrm{CO}_{2}$, and crab presence), with 8 replicates in each treatment ( $\mathrm{N}=8$ for all statistical analyses). While the fully orthogonal design led to lower replication within treatments and related increased chance of Type II error, it ensured that any interactions between temperature, elevated $\mathrm{CO}_{2}$, and crab presence could be accounted for, and that results could be attributed to individual factors. Flowing seawater from Monterey Bay (seawater intake at $\sim 17 \mathrm{~m}$ depth, $300 \mathrm{~m}$ offshore from the Monterey Bay Aquarium Research Institute) was pumped into a 38 l overflow tank connected to two 381 header tanks, each with 32 bulkhead fittings to supply a constant rate of water flow $\left(0.4 \mathrm{l} \mathrm{min}^{-1}\right)$ to each experimental tank. One header tank was bubbled with air, and the other was bubbled with an air/ $/ \mathrm{CO}_{2}$ gas mixture sufficient to maintain a $\mathrm{pH}$ reduction of 0.3 units (total $\mathrm{pH}$ scale). The 8 treatment combinations were randomly assigned to experimental tanks, after which the appropriate water supply tubing was connected. The $\mathrm{CO}_{2}$ treatment was applied to a header tank because of the logistical challenges of having separate computer-controlled $\mathrm{CO}_{2}$ supply for all 32 high$\mathrm{CO}_{2}$ tanks (to offset from incoming ambient seawater $\mathrm{pH}$ ). While this means that high $\mathrm{CO}_{2}$ tanks were not true replicates, similar header tank systems have been used previously for OA research (e.g. Taylor et al. 2014), and it was the only feasible way to maintain a consistent offset from the naturally fluctuating $\mathrm{pH}$ of the incoming seawater from Monterey Bay.

Table 1. Mean $( \pm \mathrm{SE})$ sizes of organisms used in these experiments (at the start of the experiments); Est.: estimated

\begin{tabular}{|lcccccc|}
\hline & $\begin{array}{c}\text { Carapace } \\
\text { width }(\mathrm{mm})\end{array}$ & $\begin{array}{c}\text { Length } \\
(\mathrm{mm})\end{array}$ & $\begin{array}{c}\text { Immersed } \\
\text { weight }(\mathrm{g})\end{array}$ & $\begin{array}{c}\text { Air weight } \\
(\mathrm{g})\end{array}$ & $\begin{array}{c}\text { Est. shell } \\
\text { weight }(\mathrm{g})\end{array}$ & $\begin{array}{c}\text { Est. tissue } \\
\text { weight }(\mathrm{g})\end{array}$ \\
\hline Pachygrapsus crassipes & $24.0 \pm 0.41$ & - & - & - & - & - \\
Nucella ostrina & - & $1.67 \pm 0.016$ & $0.42 \pm 0.011$ & $1.00 \pm 0.025$ & $0.70 \pm 0.019$ & $0.31 \pm 0.008$ \\
Haliotis rufescens & - & $1.56 \pm 0.009$ & $0.09 \pm 0.001$ & $0.43 \pm 0.007$ & $0.15 \pm 0.002$ & $0.28 \pm 0.005$ \\
\hline
\end{tabular}



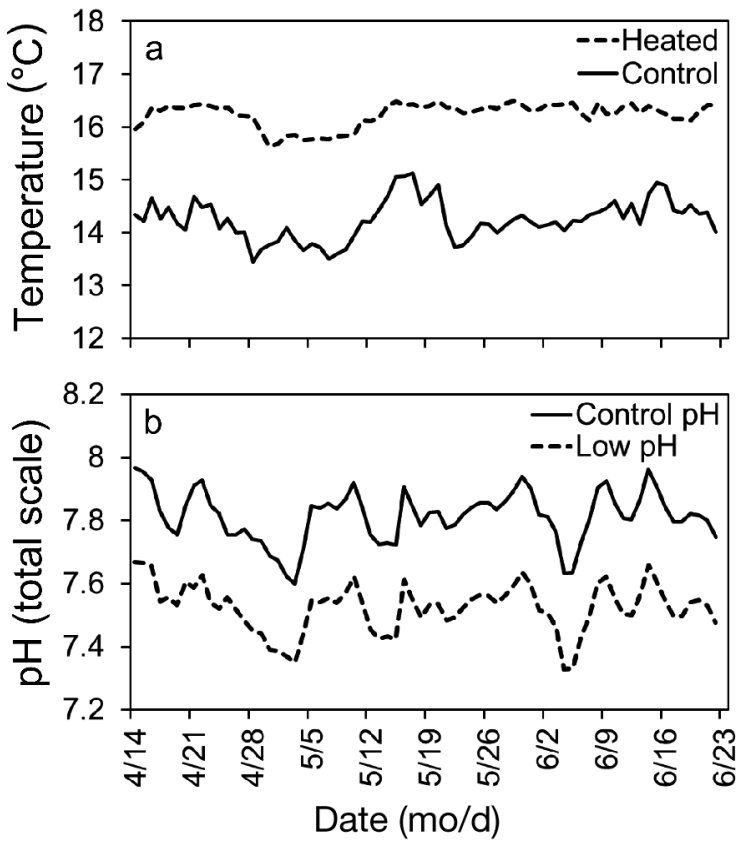

Fig. 1. Daily mean temperatures and $\mathrm{pH}$ values from control and treatment conditions. (a) Heated treatments were approximately $2^{\circ} \mathrm{C}$ warmer than controls, while (b) low $\mathrm{pH}$ (high $\mathrm{CO}_{2}$ ) treatments were $0.3 \mathrm{pH}$ units lower. These values are all shown over the duration of the $10 \mathrm{wk}$ experiment,

from 14 April to 23 June 2016, as shown on the $x$-axis

\section{Temperature and $\mathrm{CO}_{2}$ control system}

A $-0.3( \pm 0.02) \mathrm{pH}$ unit offset from the ambient $\mathrm{pH}$ of incoming fresh seawater (from Monterey Bay) was maintained in the header tank (Fig. 1) producing reduced-pH seawater using LabVIEW ${ }^{\mathrm{TM}}$ (National Instruments) software with a proportional-integralderivative controller that regulated the flow of $\mathrm{CO}_{2}$ to the tank through a proportional solenoid valve. We used this variable system to incorporate naturally fluctuating $\mathrm{pH}$, which is rarely included in OA experiments (Hofmann et al. 2010). Each header tank was equipped with a Vernier ${ }^{\mathrm{TM}}$ Tris-compatible $\mathrm{pH}$ sensor (accuracy $\pm 0.02 \mathrm{pH}$ units), which supplied real-time data to the $\mathrm{CO}_{2}$ control module and was logged once $\mathrm{s}^{-1}$ for later inspection. The $\mathrm{pH}$ sensors were calibrated weekly with $\mathrm{pH} 7$ and $\mathrm{pH} 10$ buffers (ThermoFisher Scientific), and accuracy of the $\mathrm{pH}$ sensors was tested by confirming $\mathrm{pH}$ measurements with a UV spectrophotometer (Shimadzu UV-1601). We assessed carbonate chemistry of the seawater by measuring total alkalinity 9 times over the course of the experiment with an SI Analytics Titroline 7000, and then calculating $\mathrm{pCO}_{2}$, total $\mathrm{CO}_{2}\left(\mathrm{TCO}_{2}\right)$, and calcite and aragonite saturation states for each treatment using CO2SYS (Lewis \& Wallace 1998) (Table 2).

We used heat exchangers with $1000 \mathrm{~W}$ SmartOne EasyPlug $^{\mathrm{TM}}$ titanium immersion heaters (Process Technology) to maintain 2 temperature treatments (ambient and $+2^{\circ} \mathrm{C}$ ); $8 \mathrm{~m}$ long tubing leading from header to experimental tanks was coiled through heat exchangers. Heaters were controlled by digital temperature controllers that had probes submerged in the experimental tanks they were controlling, allowing them to maintain the $2^{\circ} \mathrm{C}$ offset (Fig. 1). Tank temperatures were measured every $20 \mathrm{~min}$ with $\mathrm{HOBO}^{\mathrm{TM}}$ pendant data loggers (accuracy $\pm 0.53^{\circ} \mathrm{C}$, Onset Computer). We chose the $\mathrm{pH}(-0.3)$ and temperature $\left(+2^{\circ} \mathrm{C}\right)$ offsets to approximate potential conditions in 2100 (IPCC 2014), and intended that these levels would be largely non-lethal, so that we could measure growth and feeding.

\section{Community experiment}

Prior to the experiment, the length and width of all organisms was determined from photographs (Pentax WG-3, Ricoh Imaging) using ImageJ (https:// imagej.nih.gov/ij/), and the wet air weight and immersed weight of abalone and whelks was measured with a Scout ${ }^{\circledR}$ Pro Electronic Balance (accuracy $\pm 0.001 \mathrm{~g}$; Ohaus). Immersed weight was the weight

Table 2. Mean seawater conditions in each of the 4 seawater condition treatments. Temperature, salinity, total alkalinity (TA), and $\mathrm{pH}$ were directly measured, while others were calculated using CO2SYS (Lewis \& Wallace 1998). TCO ${ }_{2}:$ total CO $2 ; \mathrm{pCO}_{2}$ : atmospheric partial pressure of $\mathrm{CO}_{2 i} \Omega_{\text {calc }}, \Omega_{\text {arag: }}$ saturation states of calcite and aragonite, respectively. Heated treatments were $\sim 2^{\circ} \mathrm{C}$ warmer than controls, while low $\mathrm{pH}\left(\right.$ high $\mathrm{CO}_{2}$ ) treatments were $0.3 \mathrm{pH}$ units lower than controls; SW: seawater

\begin{tabular}{|c|c|c|c|c|c|c|c|c|c|}
\hline \multicolumn{2}{|c|}{ Treatments } & \multirow[b]{2}{*}{ Salinity } & \multirow[b]{2}{*}{$\begin{array}{c}\text { Temperature } \\
\left({ }^{\circ} \mathrm{C}\right)\end{array}$} & \multirow[b]{2}{*}{$\begin{array}{c}\mathrm{pH} \\
\text { (total) }\end{array}$} & \multirow{2}{*}{$\begin{array}{c}\text { TA Means } \\
\left(\mu \mathrm{mol} \mathrm{kg} \mathrm{kg}^{-1} \mathrm{SW}\right)\end{array}$} & \multirow[b]{2}{*}{$\begin{array}{c}\mathrm{TCO}_{2} \\
\left(\mu \mathrm{mol} \mathrm{kg}{ }^{-1} \mathrm{SW}\right)\end{array}$} & \multirow[b]{2}{*}{$\begin{array}{l}\text { pCO2 } \\
\text { (patm) }\end{array}$} & \multirow[b]{2}{*}{$\Omega_{\text {calc }}$} & \multirow[b]{2}{*}{$\Omega_{\text {arag }}$} \\
\hline Temp & $\mathrm{CO}_{2}$ & & & & & & & & \\
\hline Control & Control & 33.2 & 14.24 & 7.81 & 2247.9 & 2134.23 & 743.04 & 2.32 & 1.48 \\
\hline Control & High & 33.2 & 14.24 & 7.52 & 2247.9 & 2229.50 & 1527.60 & 1.26 & 0.80 \\
\hline Heated & Control & 33.2 & 16.23 & 7.81 & 2247.9 & 2122.85 & 747.80 & 2.50 & 1.61 \\
\hline Heated & High & 33.2 & 16.23 & 7.52 & 2247.9 & 2221.01 & 1543.48 & 1.36 & 0.87 \\
\hline
\end{tabular}


of each animal underwater, which can be used in conjunction with air weights to calculate wet shell and tissue weights without dissection (as in Lord \& Whitlatch 2012). With this method, we estimated shell and tissue weights using a regression between live total immersed weight and immersed weight of empty shells (Lord \& Whitlatch 2012). We also painted the aperture lip of the whelk shells with nail polish to measure their lateral growth, which would otherwise be difficult because of their whorled shape; this was not done for abalone because their lateral growth could be easily measured in photographs.

All tanks contained 1 uncaged whelk, 1 caged whelk in a $10 \mathrm{~cm}$ diameter spherical plastic cage (Jokari ${ }^{\mathrm{TM}}$ water infusers, $2 \mathrm{~mm}$ wide openings), and 1 caged juvenile abalone in a small plastic cage $(2.5 \times$ $2.5 \times 5 \mathrm{~cm}$ ) covered in $1 \mathrm{~mm}$ holes for water flow (Zak ${ }^{\mathrm{TM}}$ plastic tea infusers). The purpose of the caged and uncaged whelks was to contrast whelk responses that were based on direct interactions with crabs and those based solely on chemical cues. There were no uncaged abalone because our other experiments suggested that $P$. crassipes would likely have eaten the juvenile abalone in short order, and it would not be possible to differentiate between seaweed eaten by abalone and $P$. crassipes. Half of the tanks each contained $1 \mathrm{crab}$, while the other half had no crabs (controls). Any crabs or whelks that died during the experiment were replaced in order to maintain the fidelity of the treatments, although only the original whelks and crabs were included in statistical analysis. Ten large mussels (20-40 mm SL) were placed weekly on the bottom of each tank and 10 were put inside each whelk cage to assess feeding; shell condition was used to determine whether mussels were consumed by whelks (drill hole in mussel shell) or crabs (broken around shell margins). Because crabs may have consumed mussels after they were drilled by whelks, this method was conservative, and may have overestimated whelk feeding in crab treatments. The mussel size range was within the range of sizes preyed upon by both crabs (Lord \& Barry 2017) and whelks (Palmer 1983). The length of any consumed mussels was measured with calipers, and the amount of mussel tissue consumed by whelks and crabs was estimated from the SL:tissue weight relationship established by Fox \& Coe (1943).

Crab feeding rates were assessed by (1) weekly $17 \mathrm{~h}$ feeding experiments with 30 juvenile $(1 \mathrm{~cm} \mathrm{SL})$ mussels, and (2) weekly measurement of dead large mussels with crushed margins. We used the $17 \mathrm{~h}$ feeding experiments with juvenile mussels because previous experiments (Lord \& Barry 2017) suggested that $P$. crassipes could have the highest impact on this size range (consuming approximately $25 \mathrm{~d}^{-1}$ ). Because a constant supply of small mussels would have required an experimentally unwieldy 50000 mussels during the $10 \mathrm{wk}$ experiment, we used shorter $17 \mathrm{~h}$ feeding trials to assess feeding rates on this size class. Crabs did not consume many of the large mussels, which were primarily provided for the whelks, but we accounted for any consumption that did occur. We provided abalone with approximately $30 \mathrm{~cm}^{2}$ pieces of seaweed, then photographed the remaining seaweed and replaced it weekly, which was more reliable than weighing seaweed.

At the end of the $10 \mathrm{wk}$ experiment, we measured all organisms, dissected whelks and abalone to directly measure shell weight, measured lateral whelk growth with a flexible ruler, and measured abalone lateral growth from photos in ImageJ. We also used a Dremel $^{\mathrm{TM}}$ to cut off and weigh the newly grown shell margin for whelks. We compared crab feeding between temperature and $\mathrm{pH}$ treatments using a 2-way ANOVA in Sigmastat ${ }^{\mathrm{TM}}$. Growth and feeding metrics for all whelk and abalone were analyzed using separate 3-way ANOVAs, with temperature, $\mathrm{pH}$, and crab presence as factors. To visually compare the relative importance of direct and indirect effects of climate change between whelks and abalone, we converted differences in feeding and shell growth to percentage change relative to controls for elevated temperature, elevated $\mathrm{CO}_{2}$, and crab presence (based on least-squared means from 3-way ANOVAs). We averaged the percentage change in feeding and growth to derive an estimate of overall effects for each of the 3 factors on whelks and abalone, then plotted these on diagrams with direct effects (temperature, $\mathrm{CO}_{2}$ ) on the $\mathrm{x}$-axis and indirect effects (response to crab presence/absence with climate change) on the $y$-axis. All raw data were posted on Figshare $^{\mathrm{TM}}$ (DOI: 10.6084/m9.figshare.3474080).

\section{RESULTS}

\section{Crabs}

Crabs ate more $(+27 \%)$ mussels in heated treatments (during $17 \mathrm{~h}$ feeding trials) but exhibited a $>50 \%$ reduction in mussel consumption under the high $\mathrm{CO}_{2}$ treatment (temperature $F_{1,28}=5.54, \mathrm{p}=$ 0.026 ; $\mathrm{pH} F_{1,28}=50.6, \mathrm{p}<0.001$; Fig. 2 ). Crab mortality was also substantially higher in high $\mathrm{CO}_{2}$ treatments, at $>50 \%$ in both high $\mathrm{CO}_{2}$ treatments compared to $\sim 10 \%$ in controls (Fig. $2 b_{\text {; }}$ for detailed 

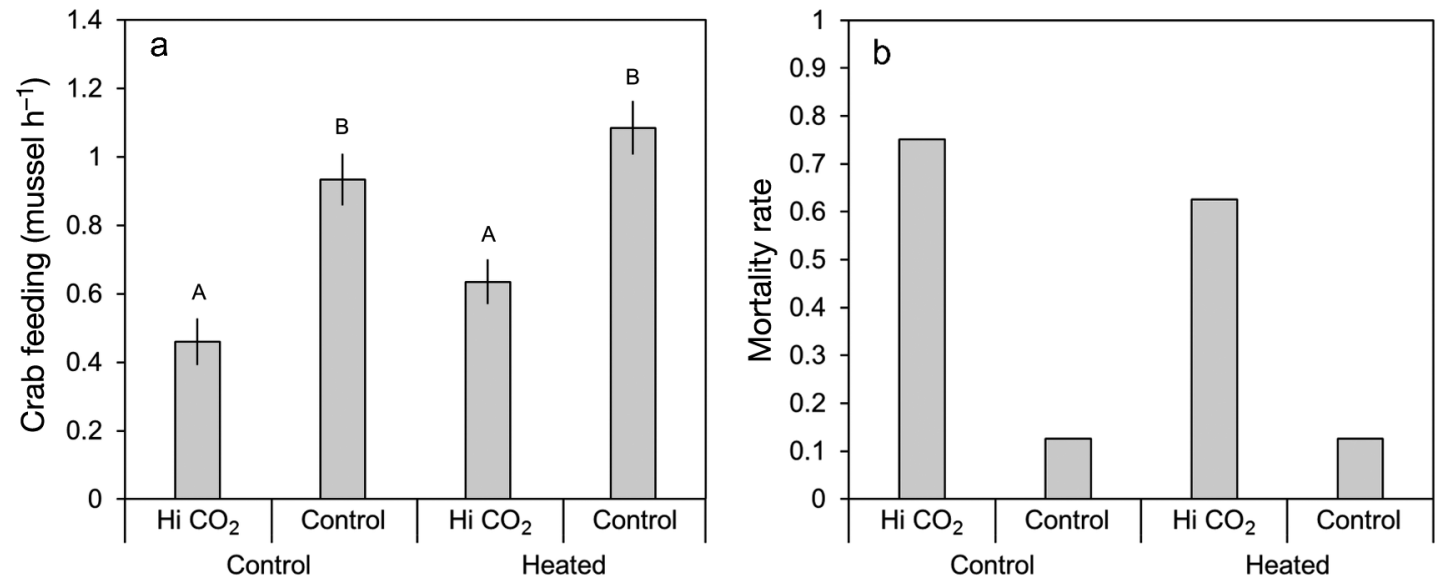

Fig. 2. (a) Feeding rate $( \pm \mathrm{SE})$ of crabs Pachygrapsus crassipes on juvenile mussels Mytilus galloprovincialis during weekly feeding experiments. Shared letters denote a lack of significant difference between bars. (b) Mortality rates of $P$. crassipes
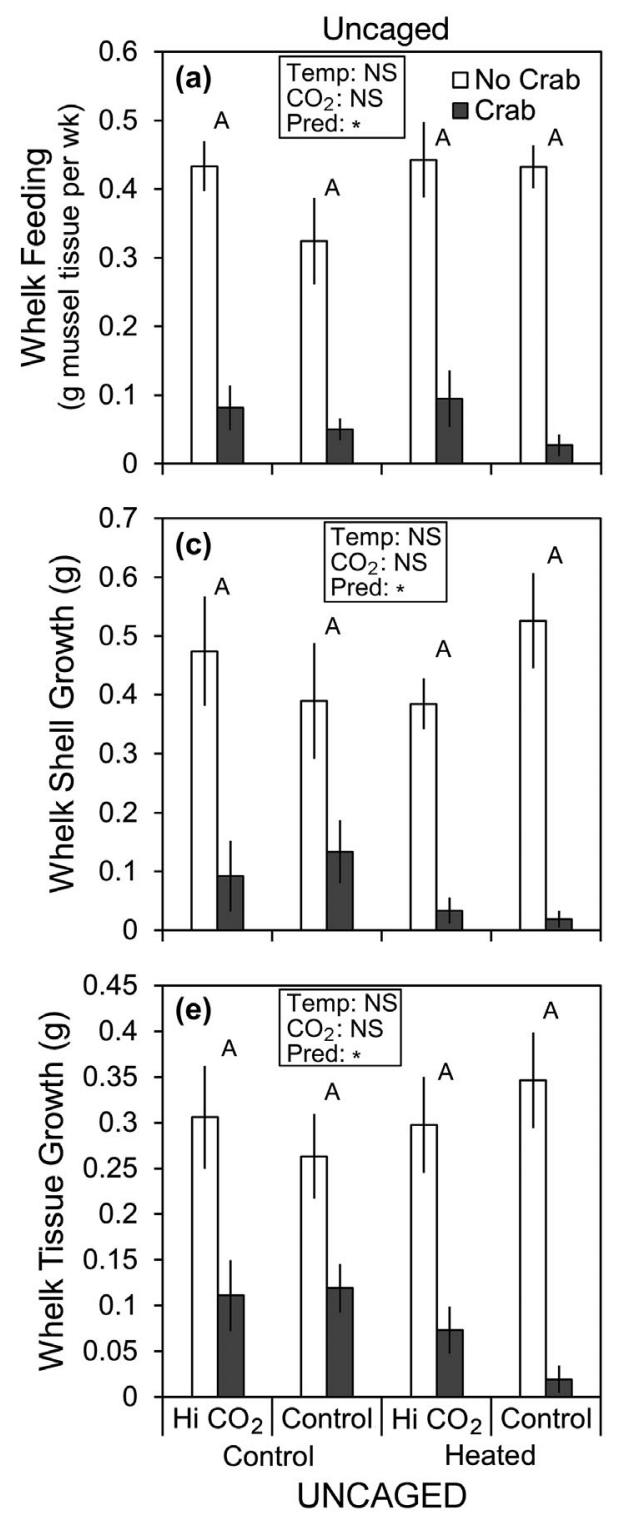

statistical results of crab and whelk feeding and growth, see Table S1 in the Supplement at www.int-res.com/ articles/suppl/m571p001_supp.pdf).

\section{Whelks}

Although no effects of temperature and $\mathrm{pH}$ treatments on whelks were detected, they reacted strongly to the presence of crabs. In stark contrast to caged whelks (which had no significant feeding response) exposed only to the 'scent' of crabs, uncaged whelks vulnerable to crab predation displayed a 4 fold reduction in feeding $\left(F_{1,56}=151.9\right.$, $\mathrm{p}<0.001$; Fig. 3a), as well as large decreases in shell weight growth $\left(F_{1,44}=\right.$ 48.54, $\mathrm{p}<0.001$; Fig. 3c) and tissue weight growth $\left(F_{1,44}=41.42, \mathrm{p}<0.001\right.$; Fig. 3e). The nonconsumptive effects (NCEs) of crabs on feeding by uncaged

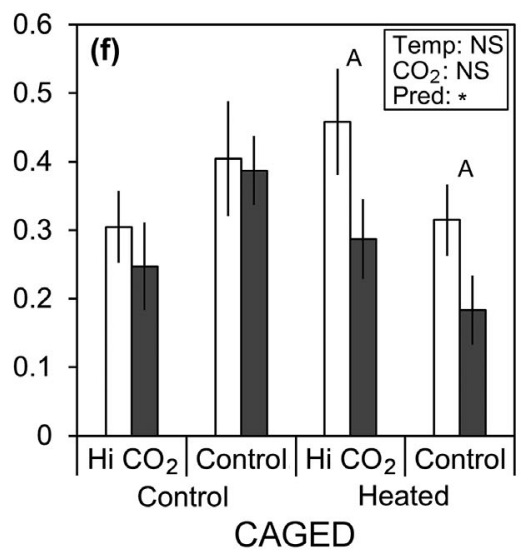

Fig. 3. Feeding and growth across all 8 treatments for caged and uncaged whelks Nucella ostrina. $(\mathrm{a}, \mathrm{b})$ Whelk feeding rates $( \pm \mathrm{SE})$ with and without crabs. $(\mathrm{c}, \mathrm{d})$ Shell growth and $(\mathrm{e}, \mathrm{f})$ tissue growth under all sets of environmental conditions. Significant differences between crab and no crab treatments under the same environmental conditions are denoted by the letter A for each pair of bars. Overall significance of each factor (Temp, $\mathrm{CO}_{2}$, Pred) across all environmental conditions is shown in boxes on each graph; ${ }^{*}$ significant $(\mathrm{p}<0.05)$, NS: not significant 


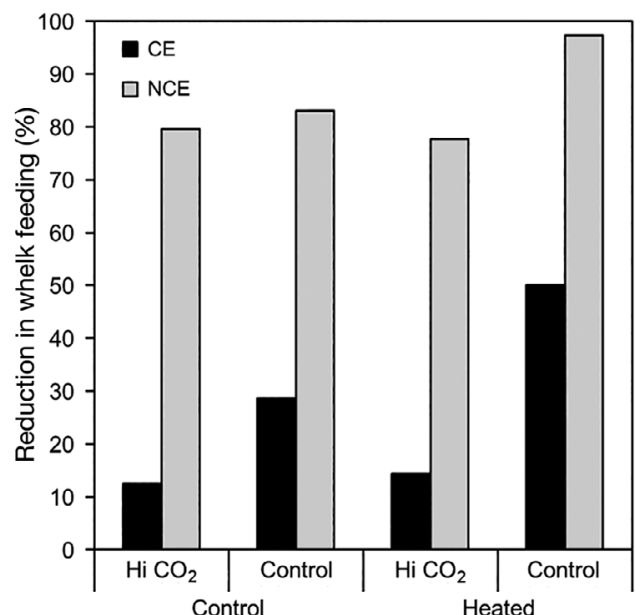

Fig. 4. Consumptive effects (CEs) and nonconsumptive effects (NCEs) of crabs Pachygrapsus crassipes on whelk Nucella ostrina feeding compared to no-crab treatments under each set of abiotic conditions. Each bar on this graph expresses the percent reduction in per capita whelk feeding in the crab treatments compared to no-crab treatments in each of the shown seawater conditions

whelks were much larger than consumptive effects (CEs; percent of whelks eaten by crabs in each treatment; Fig. 4). No more than $50 \%$ of whelks were eaten by crabs in any treatment, yet crabs caused a $>70 \%$ per capita reduction in feeding by live whelks, likely due to avoidance behavior (Fig. 4). This NCE was calculated as the difference in uncaged whelk feeding in crab treatments relative to uncaged whelk feeding in no-crab treatments with the same seawater conditions (e.g. heated, high $\mathrm{CO}_{2}$ ). While it was not quantified, the majority of the whelks in crab treatments appeared to remain near the top of the experimental tank, still submerged, but away from crabs and away from the mussel food supply.

\section{Abalone}

Abalone responded in varying degrees to each experimental factor (Fig. 5). Feeding was lower in the presence of crabs and higher in warmer water (crab $F_{1,55}=11.31, \mathrm{p}=0.002 ;$ temperature $F_{1,55}=4.745, \mathrm{p}=$ 0.034, Fig. 5a; for detailed statistical results of abalone feeding and growth, see Table S2 in the Supplement). In the presence of crabs, abalone tissue growth was reduced by $50 \%$ across treatments $\left(F_{1,55}=13.09, \mathrm{p}<0.001\right)$. Elevated $\mathrm{CO}_{2}$ was the only factor that had a significant impact on abalone shell weight growth, which was reduced by $\sim 40 \%$ under low $\mathrm{pH}$ conditions $\left(F_{1,55}=17.11, \mathrm{p}<0.001\right.$; Fig. $\left.5 \mathrm{~d}\right)$. Under all conditions, abalone produced higher amounts of shell relative to tissue in the presence of crabs (Fig. 5b) than in controls, and also displayed lower shell:tissue ratios under elevated $\mathrm{CO}_{2}$ conditions, with no effect of temperature (crab $F_{1,55}=20.65, \mathrm{p}<$ 0.001; $\mathrm{pH} F_{1,55}=5.77, \mathrm{p}=0.020$ ).
Fig. 5. Feeding and growth of abalone Haliotis rufescens across 8 treatments. (a) Abalone feeding was negatively affected by the presence of crabs Pachygrapsus crassipes ( \pm SE). (b) Changes in abalone shell:tissue ratios. These ratios were changes over the course of the experiment, so negative values indicate more tissue growth than shell growth and vice versa. (c) Abalone tissue growth. (d) Abalone shell growth. Significant differences between crab and no crab treatments under the same environmental conditions are denoted by the letter A for each pair of bars. Overall significance of each factor (Temp, $\mathrm{CO}_{2}$, Pred) across all environmental conditions is shown in boxes on each graph; ${ }^{*}$ significant $(\mathrm{p}<0.05)$, NS: not significant
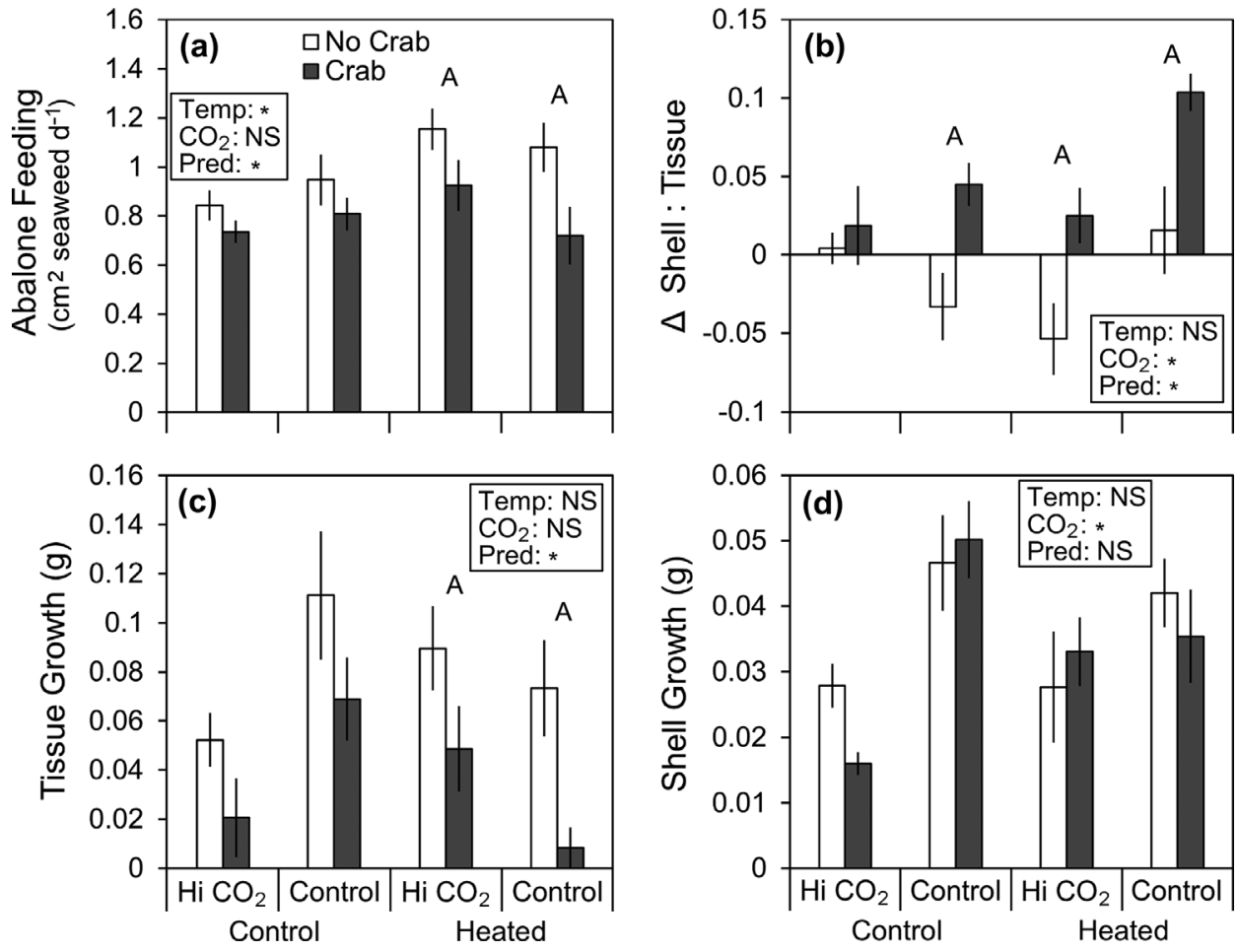

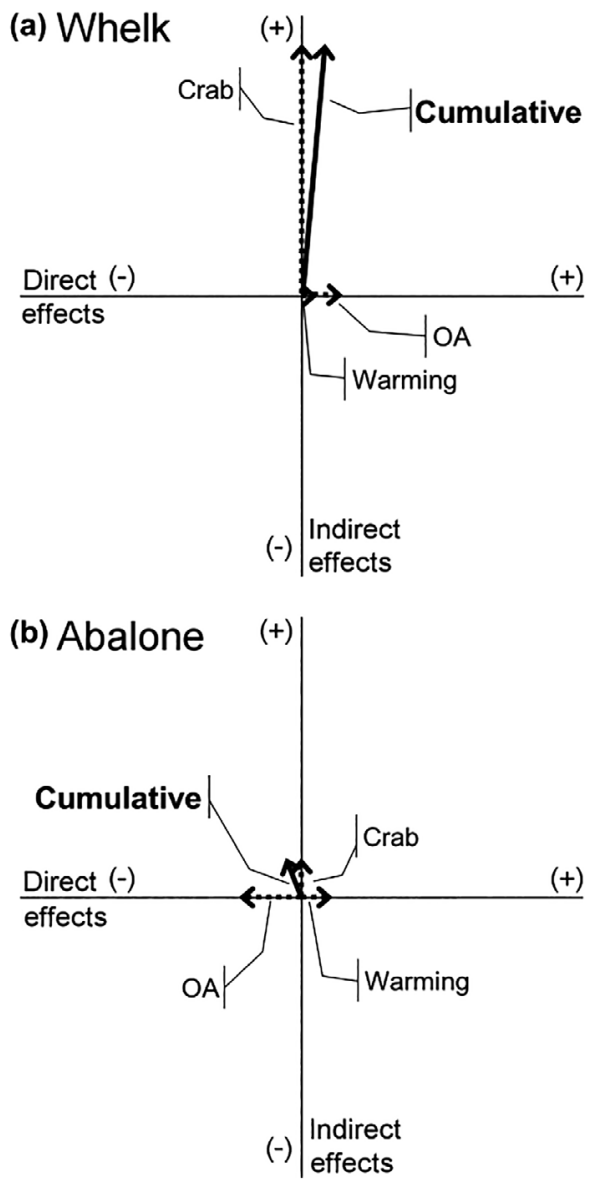

Fig. 6. Expected cumulative outcomes of direct ( $x$-axis) and indirect ( $y$-axis) effects of climate change. Lengths of arrows for (a) whelks Nucella ostrina and (b) abalone Haliotis rufescens are proportional to the percent change in net feeding and shell growth caused by each direct (elevated temperature and $\mathrm{CO}_{2}$ ) and indirect (decrease in feeding and survival of crabs Pachygrapsus crassipes) factor associated with future conditions. The strong positive response of whelks was due primarily to the decreased survival of crabs, which drastically reduce whelk feeding. Dotted lines are vector components for individual effects of crab presence, elevated $\mathrm{CO}_{2}$, and higher temperatures, and solid lines are net predictions; OA: ocean acidification

Plots of the relative impacts of direct (elevated temperature and $\mathrm{CO}_{2}$ ) and indirect effects (decreased crab survival with elevated $\mathrm{CO}_{2}$ ) on whelks and abalone showed an overall positive response to climate change for whelks, driven primarily by higher crab mortality (Fig. 6a). There were no uncaged abalone in our experiments because of potentially high predation and the inability to discern between crab and abalone feeding on seaweed, so we were unable to assess direct crab effects on abalone. Abalone displayed a negative overall response to future scenarios, due in large part to negative effects of elevated $\mathrm{CO}_{2}$ on shell production (Fig. 6b).

\section{DISCUSSION}

Our results highlight the potentially strong role of indirect interactions in shaping community responses to changes in ocean conditions driven by climate change, and suggest that cascading indirect interactions have a more pervasive impact than the direct impacts of environmental change. Society places a high priority on understanding the consequences of climate change for populations and communities, particularly in relation to the abundance and productivity of key species (e.g. fisheries). To date, our understanding of community changes in terrestrial systems is mature compared to the narrower, singlespecies scope of many studies of marine system responses to climate change. Targeting groups of interacting species allowed us to observe not only speciesspecific changes in feeding and growth that could result from climate change, but also the way that predator-prey relationships may be shaped by changing ocean conditions.

\section{Direct effects of climate change}

We saw little effect of $2^{\circ} \mathrm{C}$ heating even though higher temperatures may facilitate shell production due to increased saturation states of calcite and aragonite (Morse \& Mackenzie 1990). The levels of temperature elevation tested were mild given that they were within the seasonal range of the included species; greater heating may be necessary to induce changes beyond a slight elevation of feeding rates (Figs. $2 \& 6$ ). Because we did not observe significant responses to temperature for any of the species tested, we were not able to assess the impact of multiple stressors on these species; at higher temperatures, there may be interactions between responses to elevated $\mathrm{CO}_{2}$ and temperature (Kroeker et al. 2013). All species in this study were more robust to changes in temperature than $\mathrm{pH}$, though this may not have been the case if temperature was raised $2^{\circ} \mathrm{C}$ during the warmest time of year. This is an important difference between responses to warming and $\mathrm{OA}_{\text {; }}$ under future ocean conditions, species and communities in seasonal ecosystems will be exposed to consistently higher $\mathrm{CO}_{2}$ levels than they currently experience, while they will only experience temperatures above current maxima during the summer. However, increased temperatures at any time of year can still lead to changes in reproductive timing, feeding, growth, and competition (Lord \& Whitlatch 2015). 
Adverse effects of elevated $\mathrm{CO}_{2}$ on crab feeding and survival may be linked to the crabs' struggle to actively maintain an internal acid-base balance. We rejected our hypothesis that crabs would be unaffected by elevated $\mathrm{CO}_{2}$, as Pachygrapsus crassipes exhibited a more substantial negative response than whelks and abalone (Fig. 2), even though mollusks are generally more affected by OA (Hofmann et al. 2010, Parker et al. 2013). Other intertidal crabs can experience physiological stress under future climate conditions (Paganini et al. 2014), but the high mortality observed in this study is unusual for crabs and could be linked to the high intertidal habitat of $P$. crassipes. While untested, this species could potentially have less capacity than subtidal crabs to regulate internal acid-base balance or other key metabolic processes when continuously submerged as it was during this experiment. Higher $\mathrm{pCO}_{2}$ can depress immune responses, disrupt acid-base balance, reduce $\mathrm{O}_{2}$ transport capacity, and alter metabolic rates (Bibby et al. 2008, Fabry et al. 2008, Wood et al. 2008). Under acidified conditions, crabs expend extra energy on acid-base regulation in part by actively elevating internal bicarbonate levels to buffer internal $\mathrm{pH}_{i}$ the observed reduction in crab feeding and survival could thus be linked to this extra energetic expense and/or to a failure to control their internal pH (Appelhans et al. 2012).

Decreased abalone shell growth with higher $\mathrm{CO}_{2}$ was consistent with our expectations and with previous work, suggesting that juvenile abalone will be slower to reach mature sizes and will be increasingly vulnerable to predation by a wide range of predators under OA conditions (Fig. 5) (Griffiths \& Gosselin 2008, Byrne et al. 2011, Kim et al. 2013). Because neither abalone feeding nor tissue growth was affected by elevated $\mathrm{CO}_{2}$, the decrease in shell production was likely attributable to the challenges of producing shell material at low carbonate saturation states (Waldbusser et al. 2015). Due to coastal upwelling and cross-shelf advection of high $\mathrm{pCO}_{2}$ water, nearshore environments along the California coast are often exposed to seawater below the IPCC prediction of pH 7.8 for surface ocean waters in 2100 (Feely et al. 2008, Booth et al. 2012, IPCC 2014). Here, aragonite and calcite saturation states are now often below levels required for peak calcification by some mollusks, which may make abalone and other calcifying species especially vulnerable to further $\mathrm{pCO}_{2}$ increases (Waldbusser et al. 2015).

Unlike abalone, whelks exhibited no response to elevated $\mathrm{CO}_{2}$ (Fig. 3), which does not entirely align with previous studies on this genus of whelks.
Queirós et al. (2015) found that Nucella lapillus displayed marked dissolution under high $\mathrm{CO}_{2}$ exposure for $14 \mathrm{mo}$, so it is possible that negative effects on shells may take a long time to manifest. Nienhuis et al. (2010) showed no decrease in N. lamellosa calcification at high $\mathrm{CO}_{2}$ but did observe an increase in dissolution, unlike in the present study. While it is possible that $N$. ostrina would show a negative response to ocean acidification over a long period of time, our experiment clearly showed a far stronger deleterious effect of high $\mathrm{CO}_{2}$ on abalone; this differential vulnerability of whelk and abalone shells could be partially attributed to differences in shell chemistry (e.g. aragonite:calcite ratio, \% organic matrix, mineral microstructure) between species (Harper 2000, Menig et al. 2000, Ries 2011).

\section{Indirect effects of climate change}

Reduced whelk feeding due to behavioral avoidance of crabs was a distinct NCE that was far more important than the direct CE (predation) (Fig. 4). Predation on whelks by crabs did not exceed $50 \%$ in any treatment, but caused 75 to $95 \%$ reductions in whelk feeding due to behavioral avoidance. Whelks in crab treatments appeared to remain at the top of the experimental tanks where they were not susceptible to crab predation, presumably as a predator avoidance strategy causing the NCE (reduced feeding on mussels). This is a clear TMII, where crabs indirectly benefit mussels by reducing predation by whelks. It compares favorably to studies by Preisser et al. (2005) and Trussell et al. (2006), where TMIIs were more important than direct interactions for controlling prey populations. It is possible that whelks fed less in crab treatments because drilling mussels could be a wasted effort if there is a chance that crabs may take and eat the drilled mussels (interference competition), but behavioral avoidance of predators is more likely because it is well-documented for whelks including Nucella spp. (Trussell et al. 2006). Either way, depressed whelk feeding in the presence of crabs suggests that crabs could modulate the ecological importance of these whelks, with potentially far greater whelk predation in areas of low crab density. This was the opposite of the hypothesized indirect effect, both because of the unexpected negative response of crabs to high $\mathrm{CO}_{2}$ and because of the heretofore undescribed behavioral avoidance of $P$. crassipes by the whelk $N$. ostrina.

Our results support the notion that species responses are more variable and unpredictable when 
interspecific interactions are included in experiments (Kroeker et al. 2013, Queirós et al. 2015). The feeding, growth, and survival performance of whelks and abalone under expected future ocean conditions is likely to be predicted only weakly using solely their direct responses to warming and acidification; incorporating the role of species responses and key species interactions can provide a more comprehensive framework to estimate future community change. (Fig. 6) (Hale et al. 2011, Gaylord et al. 2015). Examining the network of 5 species included in this study does not fully incorporate the complexity of intertidal communities, but it does accentuate the importance of species interactions in determining the scope of community responses to climate change.

Diagrams showing the magnitude and direction of direct and indirect effects of climate change (Fig. 6) allow us to visualize the manner in which environmental conditions are most likely to impact species. Such diagrams are useful in any system because they help illustrate the design of the experiment and use a relatively simple approach to promote understanding of the mechanisms behind species responses to climate change. Future abundance of species controlled primarily by direct effects (e.g. abalone) can be more easily predicted by single-species studies (Fig. 6b). Primary producers and species with bottom-up control likely lend themselves better to predictions based heavily on single-species climate studies. Alternatively, species with strong predatorprey or competitive relationships (e.g. whelks, Fig. 6a) are prime candidates for community-level studies of climate change, and predictions for these species must incorporate interspecific interactions.

Predictions of species-level consequences of climate change may be misleading if they rely solely on individual physiological responses. Incorporating the essential role of indirect effects into future climate research can enhance our ability to forecast community responses to climate change. Our results highlight the differing strengths of direct and indirect effects of climate change, the interplay of which can determine the trajectory of species and communities in a changing world.

Acknowledgements. The $\mathrm{CO}_{2}$ control system could not have been built without the assistance of Chad Kecy and Chris Lovera. We used data collected by the Partnership for Interdisciplinary Studies of Coastal Oceans (PISCO), a long-term ecological consortium funded primarily by the Gordon and Betty Moore Foundation and David and Lucile Packard Foundation. Juvenile abalone were purchased from the Moss Landing Marine Labs Aquaculture Facility and Monterey Abalone Company. Field collections of mussels, crabs, whelks, and seaweed were made under California Department of Fish and Wildlife Scientific Collecting Permit SCP12647. This research was supported by the David and Lucile Packard Foundation and NSF Award no. 1416877 (to J.P.B.).

\section{LITERATURE CITED}

Appelhans YS, Thomsen J, Pansch C, Melzner F, Wahl M (2012) Sour times: seawater acidification effects on growth, feeding behaviour and acid-base status of Asterias rubens and Carcinus maenas. Mar Ecol Prog Ser 459: 85-98

Armitage AR, Fong P (2006) Predation and physical disturbance by crabs reduce the relative impacts of nutrients in a tidal mudflat. Mar Ecol Prog Ser 313:205-213

*Aschaffenburg MD (2008) Different crab species influence feeding of the snail Nucella lapillus through trait-mediated indirect interactions. Mar Ecol 29:348-353

*Bibby R, Widdicombe S, Parry H, Spicer J, Pipe R (2008) Effects of ocean acidification on the immune response of the blue mussel Mytilus edulis. Aquat Biol 2:67-74

Booth JAT, McPhee-Shaw EE, Chua P, Kingsley E and others (2012) Natural intrusions of hypoxic, low pH water into nearshore marine environments on the California coast. Cont Shelf Res 45:108-115

* Braby CE, Somero GN (2006) Ecological gradients and relative abundance of native (Mytilus trossulus) and invasive (Mytilus galloprovincialis) blue mussels in the California hybrid zone. Mar Biol 148:1249-1262

*Borne M, Ho M, Wong E, Soars NA and others (2011) Unshelled abalone and corrupted urchins: development of marine calcifiers in a changing ocean. Proc R Soc Lond B Biol Sci 278:2376-2383

Cassone BJ, Boulding EG (2006) Genetic structure and phylogeography of the lined shore crab, Pachygrapsus crassipes, along the northeastern and western Pacific coasts. Mar Biol 149:213-226

Clemente S, Hernández JC, Montaño-Moctezuma G, Russell MP, Ebert TA (2013) Predators of juvenile sea urchins and the effect of habitat refuges. Mar Biol 160:579-590

* Coleman DW, Byrne M, Davis AR (2014) Molluscs on acid: gastropod shell repair and strength in acidifying oceans. Mar Ecol Prog Ser 509:203-211

* Comeau S, Gorsky G, Jeffree R, Teyssie JL, Gattuso JP (2009) Impact of ocean acidification on a key Arctic pelagic mollusc (Limacina helicina). Biogeosciences 6: 1877-1882

* Davis AR, Coleman D, Broad A, Byrne M, Dworjanyn SA, Przeslawski R (2013) Complex responses of intertidal molluscan embryos to a warming and acidifying ocean in the presence of UV radiation. PLOS ONE 8:e55939

* Elliott JK, Leggett WC (1996) The effect of temperature on predation rates of a fish (Gasterosteus aculeatus) and a jellyfish (Aurelia aurita) on larval capelin (Mallotus villosus). Can J Fish Aquat Sci 53:1393-1402

Fvans F, Langdon CD (2000) Co-culture of dulse Palmaria mollis and red abalone Haliotis rufescens under limited flow conditions. Aquaculture 185:137-158

Fabry VJ, Seibel BA, Feely RA, Orr JC (2008) Impacts of ocean acidification on marine fauna and ecosystem processes. ICES J Mar Sci 65:414-432

* Feely RA, Sabine CL, Hernendez-Ayon JM, Ianson D, Hales B (2008) Evidence for upwelling of corrosive 'acidified' water onto the continental shelf. Science 320:1490-1492 
Fox DL, Coe WR (1943) Biology of the California sea-mussel (Mytilus californianus). J Exp Zool 93:205-249

Gaylord B, Hill TM, Sanford E, Lenz EA and others (2011) Functional impacts of ocean acidification in an ecologically critical foundation species. J Exp Biol 214:2586-2594

Gaylord B, Kroeker KJ, Sunday JM, Anderson KM and others (2015) Ocean acidification through the lens of ecological theory. Ecology 96:3-15

* Griffiths AM, Gosselin LA (2008) Ontogenetic shift in susceptibility to predators in juvenile northern abalone, Haliotis kamtschatkana. J Exp Mar Biol Ecol 360:85-93

Hale R, Calosi P, McNeill L, Mieszkowska N, Widdicombe S (2011) Predicted levels of future ocean acidification and temperature rise could alter community structure and biodiversity in marine benthic communities. Oikos 120: 661-674

Harper EM (2000) Are calcitic layers an effective adaptation against shell dissolution in the Bivalvia? J Zool (Lond) 251:179-186

Hofmann GE, Barry JP, Edmunds PJ, Gates RD, Hutchins DA, Klinger T, Sewell MA (2010) The effect of ocean acidification on calcifying organisms in marine ecosystems: an organism-to-ecosystem perspective. Annu Rev Ecol Evol Syst 41:127-147

IPCC (Intergovernmental Panel on Climate Change) (2014) Summary for policymakers. Climate change 2014 synthesis report. Contribution of Working Groups I, II and III to the Fifth Assessment Report of the Intergovernmental Panel on Climate Change. IPCC, Geneva

Kim TW, Barry JP, Micheli F (2013) The effects of intermittent exposure to low-pH and low-oxygen conditions on survival and growth of juvenile red abalone. Biogeosciences 10:7255-7262

Kroeker KJ, Kordas RL, Crim R, Hendriks IE and others (2013) Impacts of ocean acidification on marine organisms: quantifying sensitivities and interaction with warming. Glob Change Biol 19:1884-1896

Lewis E, Wallace DWR (1998) Program developed for $\mathrm{CO}_{2}$ system calculations. ORNL/CDIAC-105. Carbon Dioxide Information Analysis Center, Oak Ridge National Laboratory, US Department of Energy, Oak Ridge, TN

* Loiterton BM, Sundbom M, Vrede T (2004) Separating physical and physiological effects of temperature on zooplankton feeding rate. Aquat Sci 66:123-129

Lord JP, Barry JP (2017) Juvenile mussel and abalone predation by the lined shore crab Pachygrapsus crassipes. J Shellfish Res 36:209-213

Lord JP, Whitlatch RB (2012) Inducible defenses in the eastern oyster Crassostrea virginica Gmelin in response to the presence of the predatory oyster drill Urosalpinx cinerea Say in Long Island Sound. Mar Biol 159:1177-1182

* Lord JP, Whitlatch RB (2013) Impact of temperature and prey shell thickness on feeding of the oyster drill Urosalpinx cinerea Say. J Exp Mar Biol Ecol 448:321-326

Lord JP, Whitlatch RB (2015) Predicting competitive shifts and responses to climate change based on latitudinal distributions of species assemblages. Ecology 96:1264-1274

Menge BA (1995) Indirect effects in marine rocky intertidal interaction webs: patterns and importance. Ecol Monogr 65:21-74

Menig R, Meyers MH, Meyers MA, Vecchio KS (2000) Quasi-static and dynamic mechanical response of Haliotis rufescens (abalone) shells. Acta Mater 48:2383-2398

Morse JW, Mackenzie FT (1990) Geochemistry of sedimentary carbonates. Elsevier, Amsterdam
Nienhuis S, Palmer AR, Harley CDG (2010) Elevated $\mathrm{CO}_{2}$ affects shell dissolution rate but not calcification rate in a marine snail. Proc R Soc Lond B Biol Sci 277:2553-2558

* Paganini AW, Miller NA, Stillman JH (2014) Temperature and acidification variability reduce physiological performance in the intertidal zone porcelain crab Petrolisthes cinctipes. J Exp Biol 217:3974-3980

Palmer AR (1983) Growth rate as a measure of food value in thaidid gastropods: assumptions and implications for prey morphology and distribution. J Exp Mar Biol Ecol 73:95-124

* Parker LM, Ross PM, O'Connor WA, Pörtner HO, Scanes E, Wright JM (2013) Predicting the response of molluscs to the impact of ocean acidification. Biology (Basel) 2: 651-692

* Peacor SD, Werner EE (2001) The contribution of trait-mediated indirect effects to the net effects of a predator. Proc Natl Acad Sci USA 98:3904-3908

* Preisser EL, Bolnick DI, Benard ME (2005) Scared to death? The effects of intimidation and consumption in predatorprey interactions. Ecology 86:501-509

* Queirós AM, Fernandes JA, Faulwetter S, Nunes J and others (2015) Scaling up experimental ocean acidification and warming research: from individuals to the ecosystem. Glob Change Biol 21:130-143

* Ries JB (2011) Skeletal mineralogy in a high- $\mathrm{CO}_{2}$ world. J Exp Mar Biol Ecol 403:54-64

* Sanford E (1999) Regulation of keystone predation by small changes in ocean temperature. Science 283:2095-2097

* Sanford E, Gaylord B, Hettinger A, Lenz EA, Meyer K, Hill TM (2014) Ocean acidification increases the vulnerability of native oysters to predation by invasive snails. Proc R Soc Lond B Biol Sci 281:20132681

Schmitz OJ, Beckerman AP, O'Brien KM (1997) Behaviorally mediated trophic cascades: effects of predation risk on food web interactions. Ecology 78:1388-1399

Schmitz OJ, Krivan V, Ovadia O (2004) Trophic cascade: the primacy of trait-mediated indirect interactions. Ecol Lett 7:153-163

* Shimono H, Bunce JA (2009) Acclimation of nitrogen uptake capacity of rice to elevated atmospheric $\mathrm{CO}_{2}$ concentration. Ann Bot 103:87-94

* Strauss SY (1991) Indirect effects in community ecology: their definition, study, and importance. Trends Ecol Evol 6:206-210

*Taylor JR, Lovera C, Whaling PJ, Buck KR, Pane EF, Barry JP (2014) Physiological effects of environmental acidification in the deep-sea urchin Strongylocentrotus fragilis. Biogeosciences 11:1413-1423

*Trussell GC, Ewanchuk PJ, Matassa CM (2006) Habitat effects on the relative importance of trait- and densitymediated indirect interactions. Ecol Lett 9:1245-1252

*Waldbusser GG, Brunner EL, Haley BA, Hales B, Langdon CJ, Prahl FG (2015) Saturation-state sensitivity of marine bivalve larvae to ocean acidification. Nat Clim Change 5: 273-280

Walther G, Post E, Convey P, Menzel A and others (2002) Ecological responses to recent climate change. Nature 416:389-395

* Werner EE, Peacor SD (2003) A review of trait-mediated indirect interactions in ecological communities. Ecology 84:1083-1100

* Wood HL, Spicer JI, Widdicombe S (2008) Ocean acidification may increase calcification rates, but at a cost. Proc $\mathrm{R}$ Soc Lond B Biol Sci 275:1767-1773

Submitted: October 17, 2016; Accepted: April 7, 2017

Proofs received from author(s): May 4, 2017 